\title{
The Adair Site: Caddo Relations through Ceramic Analysis
}

Joanne D. Starr

Unknown

Follow this and additional works at: https://scholarworks.sfasu.edu/ita

Part of the American Material Culture Commons, Archaeological Anthropology Commons, Environmental Studies Commons, Other American Studies Commons, Other Arts and Humanities Commons, Other History of Art, Architecture, and Archaeology Commons, and the United States History Commons

Tell us how this article helped you.

This Article is brought to you for free and open access by the Center for Regional Heritage Research at SFA ScholarWorks. It has been accepted for inclusion in Index of Texas Archaeology: Open Access Gray Literature from the Lone Star State by an authorized editor of SFA ScholarWorks. For more information, please contact cdsscholarworks@sfasu.edu. 


\section{The Adair Site: Caddo Relations through Ceramic Analysis \\ Creative Commons License \\ (c) $($ ) (8)}

This work is licensed under a Creative Commons Attribution-NonCommercial 4.0 International License 


\title{
The Adair Site: Caddo Relations through Ceramic Analysis
}

\author{
Joanne DeMaio Starr
}

The Adair site (3GA1), located in the Upper Ouachita River Valley in Garland County, Arkansas is an Upper Ouachita Caddo site. The people at the site are presume to be at the center of cultural dominance for the area and had interaction with Caddo sites in the region. This article explores this by studying the whole vessel collections that were excavated at the Adair site in the 1930s. Comparing the Adair collection to three other Caddo sites provides information about the social standing of the Adair site, its relations with other sites, and how it fits into the greater fabric of Caddo culture in the Upper Ouachita River Valley.

\section{Introduction}

The Adair site (3GA1) is located in the Upper Ouachita River Valley, 25 miles north of Hot Springs, Arkansas and three miles northwest of the now inundated town of Buckville, Arkansas (Figure 1). The site has been the subject of two excavations, both done by the University of Arkansas Museum and its former curator, Samuel C. Dellinger (Dellinger and Dickinson 1939; see also Mainfort 2008). The first excavation was conducted from 1929 to 1931 and was part of a larger project to salvage sites in the Ouachita River Valley from the looting of mostly of whole vessels from graves. Although there was only minor funding designated for each site within the salvage project, Dellinger's notes indicate they were able to excavate a large cemetery on the south side of the Adair site (Dellinger and Dickinson 1939). The site was also excavated by Dellinger as part of a Works Projects Administration (WPA) funded expedition in the late 1930s, when it was determined that the site was to be inundated by the construction of Blakely Dam across the Ouachita River and the formation of Lake Ouachita. Dellinger obtained WPA funds to salvage what they could from Adair and surrounding sites, such as the Poole site (Wood 1981). The WPA excavations at Adair ended in 1939 and the landscape was inundated by Lake Ouachita in the early 1950 s.

The Adair site has long been considered important in the Upper Ouachita River Valley largely because it is the only Upper Ouachita site in which a pyramidal earthen mound is present. The site was composed of a single three-meter-high mound, at least two additional low mounds, two borrow pits, several structure floors, middens, and at least one cemetery (Early 1982:226, 228). Ann Early (1982) first suggested that the Adair site was home to Caddo elite based on her analysis of Caddo settlement systems. In this analysis, Early defined five types of Caddo settlements in the Ouachita Mountains, which include diffuse activity centers, focal activity

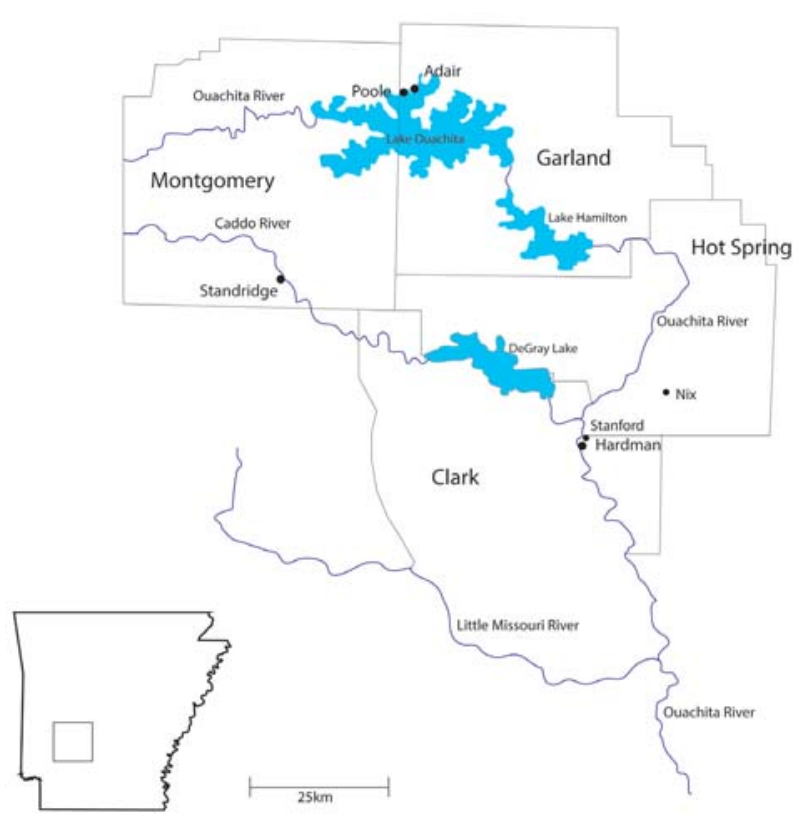

Figure 1. Map showing the location of the Adiar site.

centers, low mound clusters, cemeteries, and mound centers (Early 1982:226). Although the Upper Ouachita River Valley is a large area, the number of known sites in the area at the time of her research was only 57 , with the majority of sites classified as smaller focal or diffuse activity centers (Early 1982:226).

Although there were likely economic, political, religious, or social interactions among Adair and neighboring sites within the Upper Ouachita River Valley, which sites and how far interaction extended within and outside the river valley is unknown. In order to explore potential interaction, I discuss a comparison of pottery collections as a measure of proxy interaction by examining sites contemporaneous with Adair that are situated at successive distances and suggest possible social, economic, and political connections. Whole vessel data from Adair and three neighboring sites are compared to examine connections and interactions. Comparative 


\begin{tabular}{|l|r|r|r|r|}
\hline \multicolumn{1}{|c|}{ Decoration Type } & $\begin{array}{r}\text { \# of } \\
\text { Vessels }\end{array}$ & $\begin{array}{r}\text { Percent } \\
\text { of Total } \\
\text { Vessels }\end{array}$ & $\begin{array}{c}\text { \# of } \\
\text { Vessels }\end{array}$ & $\begin{array}{r}\text { Percent } \\
\text { of Total } \\
\text { Vessels }\end{array}$ \\
\hline Poole Plain & 59 & $29.50 \%$ & 25 & $34.00 \%$ \\
\hline Friendship Engraved & 15 & $7.50 \%$ & 12 & $16.00 \%$ \\
\hline Fosters Trailed Incised & 12 & $6.00 \%$ & 5 & $7.00 \%$ \\
\hline Seed Jar & 11 & $5.50 \%$ & 1 & $1.00 \%$ \\
\hline Maydelle Incised & 9 & $4.50 \%$ & & \\
\hline Blakely Engraved & 8 & $4.00 \%$ & 2 & $3.00 \%$ \\
\hline Hempsted Engraved & 5 & $2.50 \%$ & & \\
\hline Keno Trailed & 5 & $2.50 \%$ & & \\
\hline Means Engraved & 5 & $2.50 \%$ & 3 & $4.00 \%$ \\
\hline Moore Noded & 5 & $2.50 \%$ & 2 & $3.00 \%$ \\
\hline Taylor Engraved & 5 & $2.50 \%$ & & \\
\hline Adair Engraved & 4 & $2.00 \%$ & & \\
\hline Hodges Engraved & 4 & $2.00 \%$ & & \\
\hline Hudson Engraved & 4 & $2.00 \%$ & & \\
\hline Sanford Puncated & 4 & $2.00 \%$ & 2 & $3.00 \%$ \\
\hline Belcher Engraved & 3 & $1.50 \%$ & & \\
\hline Woodward Plain & 3 & $1.50 \%$ & & \\
\hline DeRoche Incised & 2 & $1.00 \%$ & & \\
\hline Garland Engraved & 2 & $1.00 \%$ & & \\
\hline Maxed Noded Redware & 2 & $1.00 \%$ & & \\
\hline Military Road Incised & 2 & $1.00 \%$ & 3 & $4.00 \%$ \\
\hline Avery Engraved & 1 & $0.40 \%$ & 1 & $1.00 \%$ \\
\hline Hardman Engraved & 1 & $0.40 \%$ & & \\
\hline East Incised & 1 & $0.40 \%$ & 2 & $3.00 \%$ \\
\hline Killough Pinched & 1 & $0.40 \%$ & & \\
\hline Ponteau Plain & 1 & $0.40 \%$ & & \\
\hline Sinner Linear Puncated & 1 & $0.40 \%$ & & \\
\hline Williams Plain & & & 3 & $4.00 \%$ \\
\hline Dunkin Incised & & & 2 & $3.00 \%$ \\
\hline Haley Engraved & & & 2 & $3.00 \%$ \\
\hline Hickory Fine Engraved & & & 1 & $1.00 \%$ \\
\hline Taylor Engraved & & & 1 & $1.00 \%$ \\
\hline TOTAL & $86.90 \% *$ & 67 & $91.00 \% *$ \\
\hline * Untypd & & & & \\
\hline
\end{tabular}

* Untyped vessels are not added in the total vessel count for each site.

Table 1. Whole vessel collection from the Adair and Poole sites with percentages of total

sites were selected based on their contemporaneity and that they all have been subject to documented ceramic analyses. Comparative sites include the Poole site (3GA3) located approximately $3 \mathrm{~km}$ from Adair (Wood 1981), the Standridge site (3MN53) located approximately $33 \mathrm{~km}$ from Adair (Early 1988), and Hardman (3CL418) located $63 \mathrm{~km}$ from Adair (see Figure 1).

The Adair collection analyzed in this research consists of 201 whole vessels with 175 vessel types and 26 untyped (Table 1) The untyped vessels are not included in Table 1. Measurements of each vessel were taken using the Arkansas Archeological Survey (ARAS) Ceramic Vessel Documentation Form (DeMaio 2013). Once all measurements were taken from each vessel, a Caddo pottery type was assigned, if applicable. Type descriptions were assigned using the Handbook of Texas Archeology (Suhm and Jelks 1962), from published reports from nearby or contemporary sites of ceramic analyses containing new designated types not in the Handbook, or simply marked as "untyped" due to the unique aspects of the vessel (see DeMaio 2013). Both typed and untyped vessels were additionally described using the Descriptive Classification System, also known as the Colligate System, designed by Frank Schambach. This system assigns specific names and numbers for each type of decoration technique found on either the rim or body of vessels. Of the known pottery decoration types, 26 could be correlated with types described by Shum and Jelks (1962) and in published reports. Because the untyped vessels often exhibit vast differences, it is impossible to group them together. The study of untyped vessels is a project within itself and is beyond the scope of this research. Some untyped vessels are discussed in some sections, but otherwise are left out.

\section{Comparing Adair and Poole Ceramics}

The Poole collection used in this comparison is from WPA excavations that occurred from 1939 to 1940. Artifacts from these excavations include numerous pottery sherds, chipped lithics, and 74 whole vessels similar to those excavated from Adair. Of the 74 whole vessels, 67 of them could be assigned a type and seven are classified as untyped. Excavation documentation indicates the majority of the whole vessels from the Poole collection were from an off-mound cemetery. At the Adair site, Dellinger left sparse notes on the context of the whole vessels, yet documentation and anecdotal evidence from Dellinger's colleagues suggests the Adair vessels also came from an off-mound cemetery.

The comparison collection from the Poole site was analyzed in the early 1960s, however, was not published and synthesized until nearly twenty years later. The Poole site contains both Caddo and an earlier (and larger) Fourche Maline components. Fourche Maline sites are characterized mostly by their pottery, which often included Williams Plain, Cooper Boneware, Ouachita Ironware, and LeFlore Plain (Wood 1981:52). The Fourche Maline component at Poole includes two large structures, hearths and at least two burials.

The Poole Site is located only $3 \mathrm{~km}$ from Adair and is the closest studied site to Adair. Using Early's settlement classification, the Poole site is an example of a low mound site. Two mounds were present at Poole but unlike the large mound at Adair these likely functioned as small house mounds (Wood 1981:55). Although there are no radiocarbon dates for the Poole and Adair sites, Early notes in her analysis of the Poole ceramics that the similarities of the collections indicate that they were at least partially contemporaneous (Wood 1982:56). Comparisons of the Poole and Adair collections from sites with radiocarbon dates indicate that the Poole site 
has a hypothesized occupation date of ca. A.D. 13001475/1500 and Adair site has a hypothesized occupation date of ca. A.D. 1325-1500/1525 (See DeMaio 2011:110; Early 1982:134).

Ethnohistoric data and archeological evidence indicate Caddo communities were not isolated communities. Caddo communities consisted of widely spaced houses or groups of houses with a religious and political civic center. These communities were often sprawling and could cover kilometers of land (Early 1982:202; Sabo 1992:50). Caddo society was hierarchical, and based loosely on matrilineal kin systems (Early 1982:202; Sabo 1992:50). The highest-ranking member of society was allowed certain rights, such as the ability to take a share of a family's crop and require members of the community to build mounds (Early 1982:203). The elite of a community lived in an elite center. The elite center generally had one or more earthen mounds and contained the primary residence of the elite and their family, residences of social and political officials, and religious buildings (Early 1982:202-203) As such, it is likely that Adair and Poole were part of the same community, or at least related in some way.

When comparing the collections from Adair and Poole, similarities exist in the types represented and the distribution of the types in the assemblages (see Table 1). Both collections were from mortuary collections. At both sites, the most common vessel types are Poole Plain, Friendship Engraved, Adair Engraved, and Foster Trailed-Incised. It should be noted that the analysis of Poole ceramics did not differentiate Adair Engraved vessels from the Friendship Engraved, so they are grouped together as Adair Engraved (Wood 1981:3537). Adair Engraved vessels were first described as Friendship Engraved in Suhm and Jelks in 1954. Weber and Loring reassessed the type during their reassessment of Friendship Engraved vessels in the Henderson State University Collection (Weber and Loring 1971). Adair Engraved vessels differ from Friendship Engraved because they are exclusively bottles with no neck or rim design and intricate engraved designs on the body (Suhm and Jelks 1954:Plate 23). Friendship Engraved vessels are exclusively carinated bowls.

Regardless, if the Adair Engraved counts are added to the Friendship Engraved counts at the Adair site to mirror the Poole analysis, the count increases to 19 (9.4 percent) and represents one of the most common types. Similarly, the Poole report did not distinguish Garland Engraved from Friendship Engraved. If Garland Engraved vessel types are included with the Friendship Engraved occurrences at Adair there is an increase to 17 (10.9 percent).

One pressing question is related to the provenience of the vessels from Adair. Although
Dellinger noted that the vessels came from "a large cemetery" what that exactly meant is unknown. One way to test this is to look at the Poole ceramics where we know the provenience. The whole vessel collection from Poole is from 34 burials, of which the pottery was the most common burial good and Poole Plain was the most common type. Five burials had no grave goods associated with them, and ten of the 34 graves had non-ceramic goods associated with them. Of those ten graves, they mostly contained modest, non-sociotechnic examples of chipped lithic or groundstone artifacts that did not denote any particular social standing or hierarchy (Wood 1982:55). It should be noted that the excavation of the burials was done in the 1930s and 1940s. It is possible and likely that looting had occurred previously.

From this information, a few things can be inferred. First, the similarity in design and distribution of ceramic types at Adair with Poole suggests that they likely had similar "standards" in ceramic burials goods. However, the wide array of ceramic types, including "Typical" Middle Ouachita types (Seed jars, Means Engraved, Blakely Engraved, and Military Road Incised) evident at the Adair site and not at Poole could indicate that the extent of contact for Adair was further than that of Poole or the burials at Adair were those of elites that "required" more (Wood 1982:56). Early notes that the composition and size of the Adair site is unlike any other in the Upper Ouachita (Wood 1982:55-56). The WPA excavations at Adair uncovered large building footprints not seen at Poole. Additionally, it is the most complex site in the Upper Ouachita with multiple mounds - the largest is 26 by $33 \mathrm{~m}$ at the base and nearly $9 \mathrm{~m}$ high (Dellinger and Dickinson 1939).

The connections between the Poole and Adair sites are evident in the ceramic collections. However, the ceramic data reinforces the ethnohistoric and archeological information known about the Caddo and their social practices. Although the collections show similar percentages and composition based on known types, the diversity seen at Adair and not Poole supports the hypothesis that the Poole and Adair sites were contemporaneous and likely had regular, if not sustained, interaction.

\section{Comparing Adair and Standrige Ceramics}

The Standridge site (3MN53) is located in the Upper Caddo River Valley, not far from the south fork of the Ouachita River area and approximately $36 \mathrm{~km}$ from Adair (see Figure 1). Arkansas Archeological Society members and students from the University of Arkansas excavated at Standridge in 1975-1976 as part of two annual Society digs and University of Arkansas field schools. The site has evidence of both Fourche Maline 
and Caddo occupations (Early 1988:61-62). Using Early's settlement classification, it is classified as a low mound and domestic site containing houses, burials, a single mound, and middens. Ceramic evidence from Standridge consists of approximately 3,900 sherds and 26 whole vessels (Early et al. 1988:61; Table 2). Fourteen of the whole vessels and 2,280 of the sherds are classified as untyped and are not included in the table. When comparing the Standridge collection to others in this study, it is important to understand that compared to Adair and Poole, the majority of the ceramic collections from Standridge come from domestic areas, and midden layers associated with buildings in the mound rather than burial contexts. The excavations done at Standrige were more complex than those at Adair and Poole. This includes screening excavated material, looking at multiple facets of occupation, and using modern tools to study botanical and faunal remains. Looking at the pottery at Standridge, the most common decorated known type is Friendship Engraved (38 sherds and one whole vessel) with Mill Creek Plain as the most common undecorated typed pottery (209 sherds) (Early 1988:64-65). There are 38 Poole Plain sherds and one restored Foster TrailedIncised vessel (Early 1988).

However, when looking at the untyped pottery from Adair and Standridge, there are some parallels. Early identified a group of untyped vessels from Standridge as tall-rimmed, engraved carinated bowls with oval designs on the rim and labeled "Untyped Group 4" (Early et al. 1988:82-84). During the analysis of the Adair vessels, a similar type of tall-rimmed, engraved carinated bowls was observed in the collection. These were labeled as "Untyped Group 2" (DeMaio 2013:112). Both of the "Untyped Group 4" vessels from Standridge were recovered from Feature 9 grave (Early et al. 1988:83). Although the design motifs are not identical, they share similar forms and elements (Figure 2).

Similarly, a group of untyped vessels from Adair labeled "Untyped Group 1" is similar to "Untyped Group 3" from Standridge (DeMaio 2013:113; Early 1988:Figure 4-8). Both of these have similar forms with globular or sub-globular bodies, high and vertical rims, and a rolled lip (Figure 3). Decoration on the rims is comparable as well where all have rows of vertical or diagonal incised lines. Where the vessels differ is in the exterior surface finish. The vessels from Adair have a finely burnished to polished exterior surface and the Standridge vessels are matte and smoothed. These types of jars are also present at many sites in the Upper Ouachita region, including Cain Place and the Stanford site (3CL81), and the Middle Ouachita Nix site (3HS75) (see Figure 1) (Early 1988:82). The Cain Place has no official site number, however, it was in the vicinity of the Adair and Poole site in Garland County and is likely now

\begin{tabular}{|l|r|r|r|}
\hline \multicolumn{1}{|c|}{ Decoration Type } & \multicolumn{2}{c|}{ Adair } & \multicolumn{2}{c|}{ Standridge } \\
\hline Poole Plain & 59 & 1 & \# of Vessels \\
\hline Friendship Engraved & 15 & 2 & 45 \\
\hline Fosters Trailed Incised & 12 & 1 & \\
\hline Seed Jar & 11 & & \\
\hline Maydelle Incised & 9 & & \\
\hline Blakely Engraved & 8 & & \\
\hline Hempsted Engraved & 5 & & \\
\hline Keno Trailed & 5 & 5 & \\
\hline Means Engraved & 5 & & \\
\hline Moore Noded & 5 & & \\
\hline Taylor Engraved & 5 & & \\
\hline Adair Engraved & 4 & & \\
\hline Hodges Engraved & 4 & & \\
\hline Hudson Engraved & 4 & & \\
\hline Sanford Puncated & 4 & & \\
\hline Belcher Engraved & 3 & & \\
\hline Woodward Plain & 3 & & \\
\hline DeRoche Incised & 2 & & \\
\hline Garland Engraved & 2 & & \\
\hline Maxed Noded Redware & 2 & & \\
\hline Military Road Incised & 2 & & \\
\hline Avery Engraved & 1 & & \\
\hline Hardman Engraved & 1 & & \\
\hline East Incised & 1 & & \\
\hline Killough Pinched & 1 & & \\
\hline Ponteau Plain & 1 & & \\
\hline Sinner Linear Puncated & 1 & & \\
\hline Williams Plain & & & \\
\hline Cooper Boneware & & & \\
\hline LeFlore Plain & & & \\
\hline Mill Creek Plain & & & \\
\hline Ouachita Ironware & & & \\
\hline Untyped red slipped & & & \\
\hline Ashdown Engraved & & & \\
\hline Marksville Stamped & & & \\
\hline TOTAL & & & \\
\hline
\end{tabular}

Table 2. Whole vessel collection from Adair and the whole vessel and sherd collection from the Standridge site

inundated by Lake Ouachita. Little information is known about the site, but photographs of ceramics (now part of the Lemley Collection at the Gilcrease Museum in Tulsa, Oklahoma) were used for comparisons.

In the Standridge report, Early suggests that there is a direct comparison between the pottery in the Poole collection and the pottery found from the early period of Standridge mound construction. Early notes that there are direct comparisons identifiable in sherds taken from Feature 12 at Standridge (a house floor) with Poole Plain bowls, Adair Engraved bottles, and one Friendship Engraved var. Antoine (Early 1988:101). Using these examples of typed pottery, it is suggested that all three sites were at least partly contemporary (Early 1988:101). The ceramic collections at Poole and Adair indicate a 
A.
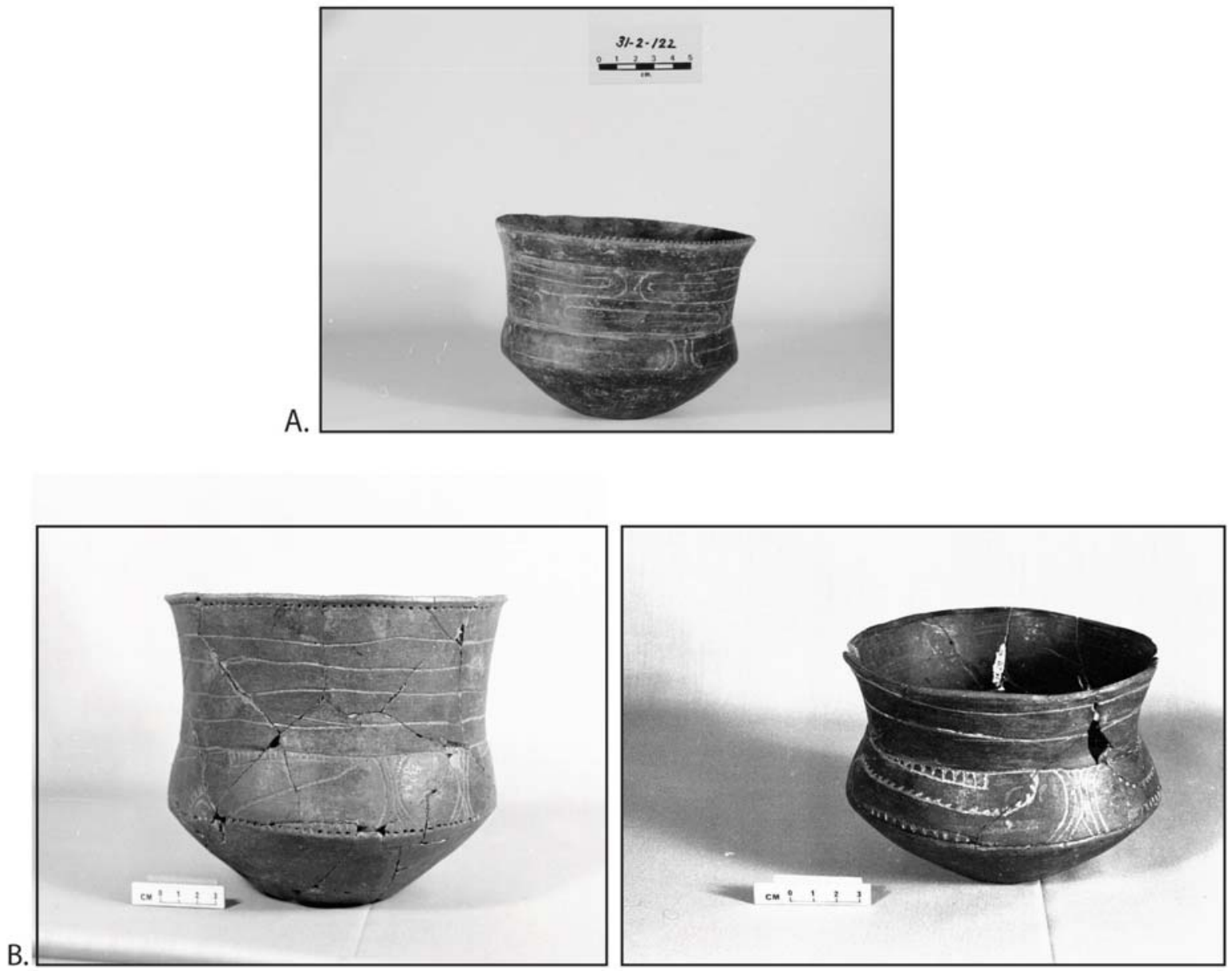

Figure 2. A. Untyped Group 2 vessel from Adair (AAS Neg. No. 920265); B. Untyped Group 4 from Standrige (AAS Neg No. 825999, 832573)

greater diversity than at Standridge. This is most likely due to the longer time span that Adair and Poole were occupied.

Unlike the Adair and Poole sites, the Standridge site has radiocarbon and archeomagnetic dates. The dates from Standridge indicate that the site was intensively occupied for a relatively short amount of time (Early 1988:155-156). The Caddo occupation at the site was most likely no longer than about one hundred years, with a possible less intensive Caddo occupation a hundred years earlier (Early 1988:155). There is evidence of a possible longer Caddo occupation, but the top-most layers of the site were plowed and eroded away and unable to be analyzed. Although the radiocarbon dates are not trustworthy (Early 1988:153), archeomagnetic data show that the dates for the site cluster from A.D. 1350-1450 (Early 1988).

The classification that Standridge was a low mound cluster indicates that domestic as well as local religious and political activities took place there. Several features at Standridge indicate that it was likely a local elite center. The Standridge report points specifically to two building footprints documented during excavations as a round structure (Feature 12), and a rectangular wall trench structure (Feature 18) (Early 1988:41). Feature 18 was buried at some point and replaced with another rectangular building in the same location (Feature 8) (Early 1988:67). These buildings were located very close together, which makes it unlikely that both structures were residences. Assemblages from Feature 12 consist of food preparation and storage, lithic debatage and reworking debris, and other artifacts that indicate it was a domestic structure. Documentation from excavations of Feature 8 indicate that it was burned at some point (Early 1988:67).

Henri Joutel, a French explorer who traveled the southeastern United States from 1684-1687 notes several things about Caddo buildings in his journals. He notes that many are round in shape, as large as 60 feet (18 $\mathrm{m})$ in diameter and are burned to the ground when they 

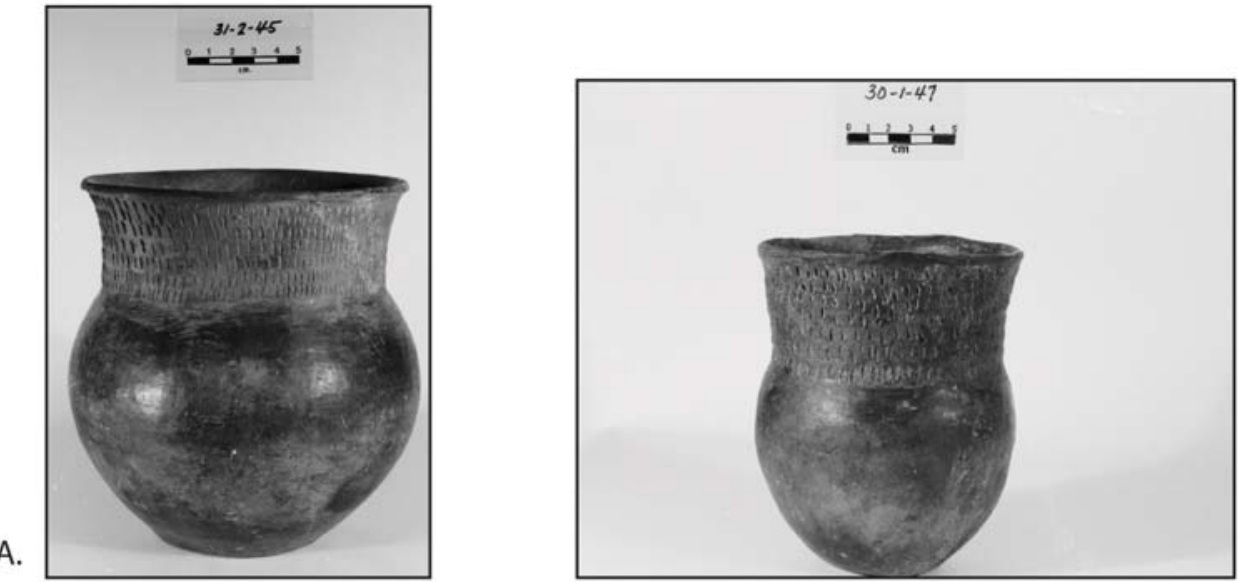

B.
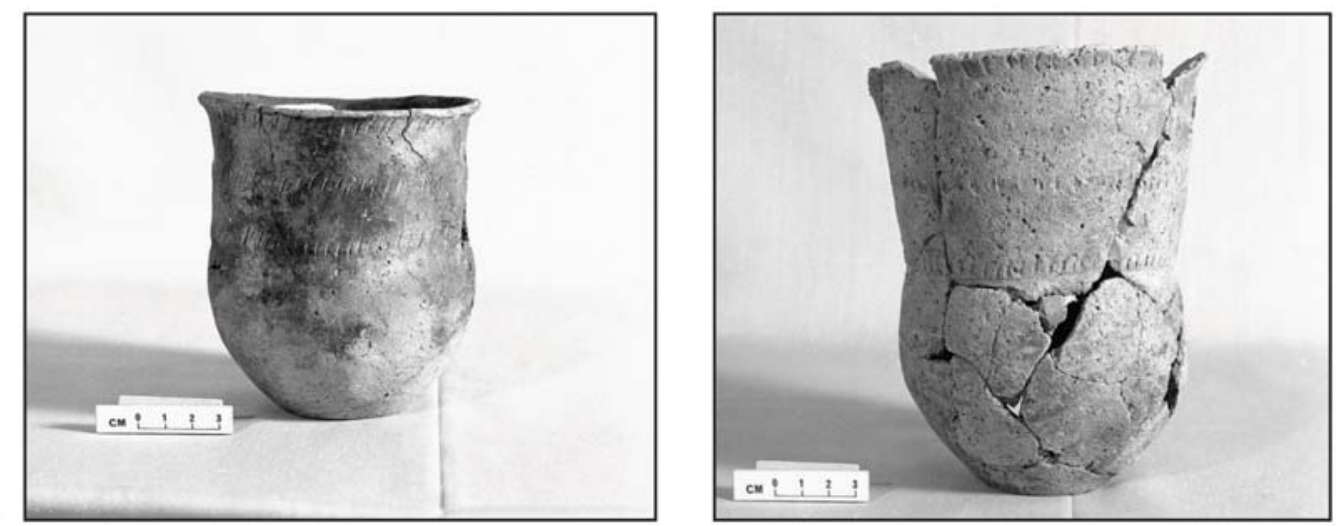

Figure 3. A. Untyped Group 1 from Adiar (AAS Neg. No. 920152, 920089); B. Untyped Group 3 from Standridge (AAS. Neg. No. 825987, 825991)

are destroyed (Joutel 1906:142). Although it is not clear where Joutel made these observations, archeological evidence correlates with his writings. Structures observed at Adair include a large (13 $\mathrm{m}$ in diameter) round structure (See Dellinger and Dickinson 1939:Feature 27) and rectangular structures (see Dellinger and Dickinson 1939:Feature 3). Although Dellinger and Dickinson did not mention the types of artifacts or interior features of the structures excavated, they did mention that several of the excavated buildings, including Features 27 and 3, were burned (Dellinger and Dickinson 1939).

The connections between the Adair and Standridge sites likely do not indicate direct contact, but rather regional trends that were present throughout the entire Upper Ouachita River Valley at the time. Ceramic types in use seem to follow similar trends, and the burials at Standridge have types that correlate with known burial goods from Poole. The sites were likely, at least partially, contemporaneous, but the archeomagentic dates and diversity of the Adair ceramic collection indicate that Adair was occupied for a longer time. Besides ceramic similarities, comparisons of house construction techniques and shapes indicate that both Standridge and Adair followed similar cultural norms.

\section{Comparing Adair and Hardman Ceramics}

The Hardman site (3CL418) is not located in the Upper Ouachita region but rather in the Middle Ouachita Region further south. This region is south of modern-day Lake Hamilton and north of Camden (see Figure 1) (Early 1982, 1993). Culturally, differences between the Upper and Middle Ouachita can be seen in pottery styles and types, house and burial patterns, and other features.

The Caddo occupation of the Hardman site is divided into four archeological phases. The MidOuachita phase (ca. A.D. 1350-1500) is contemporary with Adair (Early 1982, 1993). The distribution of the pottery at Hardman is quite different than Adair (Table 3). There are 27 types of pottery at Adair and 16 at Hardman. 


\begin{tabular}{|l|r|r|}
\hline \multicolumn{1}{|c|}{ Decoration Type } & $\begin{array}{c}\text { \# of Adair } \\
\text { Vessels }\end{array}$ & $\begin{array}{c}\text { \# of Hardman } \\
\text { Vessels }\end{array}$ \\
\hline Poole Plain & 59 & \\
\hline Friendship Engraved & 15 & 5 \\
\hline Fosters Trailed Incised & 12 & 1 \\
\hline Seed Jar & 9 & \\
\hline Maydelle Incised & 8 & \\
\hline Blakely Engraved & 5 & \\
\hline Hempsted Engraved & 5 & \\
\hline Keno Trailed & 5 & \\
\hline Means Engraved & 5 & \\
\hline Moore Noded & 5 & \\
\hline Taylor Engraved & 4 & \\
\hline Adair Engraved & 4 & \\
\hline Hodges Engraved & 4 & \\
\hline Hudson Engraved & 4 & \\
\hline Sanford Puncated & 3 & \\
\hline Belcher Engraved & 3 & \\
\hline Woodward Plain & 2 & \\
\hline DeRoche Incised & 2 & \\
\hline Garland Engraved & 2 & \\
\hline Maxed Noded Redware & 2 & \\
\hline Military Road Incised & 1 & \\
\hline Avery Engraved & 1 & \\
\hline Hardman Engraved & 1 & \\
\hline East Incised & 1 & \\
\hline Killough Pinched & 1 & \\
\hline Ponteau Plain & & \\
\hline Sinner Linear Puncated & & \\
\hline Glassell Engraved & & \\
\hline Old Town Red & & \\
\hline Karmack Brushed Incised & & \\
\hline Caney Puncated & & \\
\hline Simms Engraved & & \\
\hline Cook Engraved & & \\
\hline TOTAL & & \\
\hline & & \\
\hline
\end{tabular}

Table 3. Whole vessel types from the Adair and Hardman sites.

The types that are at both Adair and Hardman are mostly those that are common in the Middle Ouachita region. As mentioned, there are some examples of Mid-Ouachita pottery at Adair. Conversely, there are no examples of Upper Ouachita pottery, such a Poole Plain, at Hardman (Early 1993). The pottery at Adair seems to have been brought from the Middle Ouachita region, thus suggesting that there is some interaction with people who were living in the Middle Ouachita. Even though interaction is possible, the lack of Upper Ouachita pottery at Hardman suggests that the people at Adair did not have sustained interaction with the people as far south as Hardman.
As at Adair, Poole and Hardman both had offmound burials from cemeteries, but the compositions are different. One similarity that should be noted is that both the whole vessels in the Adair collection and the Hardman collection were both from mortuary settings. Poole Plain is the most common burial good in Upper Ouachita graves, but there was no Poole Plain pottery found at the Hardman site. In addition to the ceramic goods, there were non-ceramic goods interred with the Hardman burials as well. At Poole, chipped lithic and groundstone objects were the most common. Conversely, at Hardman, shells, beads, clay discs, and points were found in the burials. Although both cemeteries show modest, non-stratified burials, the differences in types of pottery and nonceramic objects suggest that the two communities were not linked. Temporal dates for ceramic types indicate that most of the graves at Hardman can be identified as later than those at Adair, Poole, or Standridge .

The comparison between Adair and Hardman shows that although these sites may have had interaction the ceramic collections would likely be more similar. If interaction between the sites occurred, it is likely the sites would have similar standards for ceramic burial goods, as evident at Adair and Poole, or at the least some minor connections in ceramic burial goods, like Poole and Standridge. Additionally, there would likely be some examples of Upper Ouachita ceramic types at Hardman. It is possible that sites between Adair and Hardman were the indirect linkages between the sites. Although they were contemporaneous, the people who lived at Adair and Hardman were separate and most likely did not have direct contact.

\section{Conclusion and Discussion}

The goal of this study was to examine the possible interaction and influence of the Adair site throughout the Ouachita region. The comparison of ceramic collections as a proxy for interaction was undertaken among the Adair site and three contemporary sites in the Upper and Middle Ouachita. This study is about the ceramic assemblage of this site. Moreover, it is about the whole vessel assemblage, which limits assumptions even more. The dataset for the Upper Ouachita River Valley is one that is incomplete, even more so than the other areas of observed Caddo culture. Because of these reasons, one has to understand that the conclusions that are made cannot be proved or even tested without much more research being done on this and other Caddo sites. It is also understood that issues arise when trying to use one aspect of culture, ceramic in this case, as a proxy for interaction. Some ceramic types have large spans of time for usage, so it can be nearly impossible to draw direct, or even indirect, observations. However, some interesting 
data can be inferred from the research listed above and as researchers, we must take the data we have, even if there are issues involved.

When looking at the four sites together, it can be understood that there was most certainly interaction between Adair and Poole. This is evident not only from the archeological data, but ethnohistoric data as well. When it comes to Adair and Standridge, it can be demonstrated that they did have some interaction, but it was likely indirect. Similarities in pottery distribution, and particularly in the untyped pottery (see Figures 2 and 3), show that there were ideas and possibly vessels exchanged between the sites. However, it is suggested that indirect linkages were more a result of regional trends in burial composition and pottery styles, rather than direct interaction. Conversely, the Adair and Hardman sites show little to no interaction and have no similarities in ceramic collections or burial goods.

The Adair site was most likely a local elite site that was the central place where people from the area would come to participate in ritual or civil ceremonies. This is evidenced by the complexity of the site, known ethnohistoric data, and diversity of the ceramic collection. It would have been a place where elites and their families would have lived with patches of hamlets and farmsteads nearby making periodic trips throughout the year to participate in governmental works or ritual activities. Because of the appearance of Middle Ouachita pottery at Adair, it is suggested that the extent of the interaction of the people at Adair would have included surrounding sites, possibly into the northernmost areas of the Middle Ouachita geographic area. The people of Adair would have utilized the Ouachita River as a way to interact with those in surrounding areas. The interaction would likely have been in the form of goods and ideas. Much of the interaction as far south as the Middle Ouachita area would likely have been indirect rather than direct. It has been recorded that Caddo communities could be very extensive spanning large swaths along rivers and streams (Early 1982:202). Although it is unknown the extent that the Adair site influence spanned, one could estimate that it was perhaps at a few kilometers, as evidenced by the assumed connections between Adair and Poole. This study of the Adair collection included only the whole vessel collection. Thousands of additional ceramic sherds, chipped lithics, and other artifacts are still unanalyzed. Additional research into the mico-stylistic variation within the whole vessel and sherd collection would be a next step in this research. Similar studies on collections from other sites have refined the typologies, identified different variations, and helped to understand the spread of manufactured goods across areas. Additional information can be inferred from these additional artifacts, which could possibly help archeologists glean more information about the Adair site and Caddo settlement systems in the Upper Ouachita River Valley.

\section{References Cited}

Dellinger, Samuel C, and Samuel D. Dickinson 1939 Excavation of the Adair Site. WPA Site Report.

DeMaio, Joanne

2013 The Adair Site: Ouachita River Valley Relations Through Ceramic Analysis. Master's thesis, Department of Anthropology, University of Arkansas, Fayetteville.

Joutel, Henri

1906 [1713] A Historical Journal of the Late Monsieur de LaSalle's Last Voyage into North America to Discover the River Mississippi. Edited by H. R Stiles. Joseph McDonough, New York.

Early, Ann M.

1982 Caddoan Settlement Systems in the Ouachita River Valley. In Arkansas Archeology in Review, edited by Neal L. Trubowitz and Marvin D. Jeter, pp. 198-232. Research Series No. 15. Arkansas Archeological Survey, Fayetteville.

1988 Standridge: Caddoan Settlement in a Mountain Environment. Research Series No. 29. Arkansas Archeological Survey, Fayetteville.

Early, Ann M. (editor).

1993 Caddoan Saltmakers in the Ouachita Valley: The Hardman Site. Research Series No. 43. Arkansas Archeological Survey, Fayetteville.

Mainfort, Robert C., Jr.

2008 Sam Dellinger: Raiders of the Lost Arkansas. University of Arkansas Press, Fayetteville.

Sabo, George, III

1992 Paths of Our Children: Historic Indians of Arkansas. Popular Series No. 3. Arkansas Archeological Survey, Fayetteville.

Schambach, Frank F.

1981 A Description and Analysis of Ceramics. In The Shallow Lake Site and Its Place in Regional Prehistory, by Marth Ann Rolingson and Frank F. Schambach, pp. 101-176. Research Series No. 12. Arkansas Archeological Survey, Fayetteville. 
Schambach, Frank. F., and John E. Miller

1984 A Description and Analysis of the Ceramics from the Cedar Grove Site (3LA97).. In Cedar Grove: An Interdisciplinary Investigation of a Late Caddo Farmstead in the Red River Valley, edited by Neal L. Trubowitz, pp. 160-290. Research Series No. 23. Arkansas Archeological Survey, Fayetteville.

Suhm, Dee Ann, and Edward B. Jelks (editors)

1962 Handbook of Texas Archeology: Type Descriptions. Special Publication No. 1, Texas Archeological Society, and Bulletin No. 4, Texas Memorial Museum, Austin.
Weber, J Cynthia, and Stephen G. Loring

1971 A Study of Friendship Engraved vessels in the Henderson State College Museum. Manuscript on File, Arkansas Archeological Survey, Fayetteville.

Wood, W. Raymond

1981 The Poole Site, 3GA3, With New Foreword and Summary by Ann M. Early. The Arkansas Archeologist 22:7-65. 